\title{
Spectinomycin hydrochloride in the treatment of uncomplicated gonorrhoea in males and females
}

\author{
M. KOUSA, A. LASSUS, R. JÄRVELÄINEN, AND O-V. RENKONEN \\ From the Out-Patients Department for Venereal Diseases, University Central Hospital, and the Department of \\ Serology and Bacteriology, Universitv of Helsinki, Finland
}

Penicillin is still the drug of choice in the treatment of gonorrhoea in most countries, but its use is becoming increasingly limited by the development of resistant strains of gonococci (Amies, 1967; Sparling, 1972; Hafermann, Cooper, and Chesney, 1973). Allergic reactions to penicillin are also a significant problem. About 3 to 5 per cent. of patients attending venereal disease clinics claim to be allergic to penicillin (Willcox, 1959; Feinberg, 1961). The figure for our out-patients department is about 6 per cent. For these reasons new antibiotics are needed, which are effective against $N$. gonorrhoeae and can be given to patients allergic to penicillin.

Spectinomycin was first used as the sulphate in the treatment of gonorrhoea and proved to be highly efficient (Laird and Taylor, 1962; Willcox, 1962; Sparling, Yobs, Billings, and Hackney, 1965; Tiedemann, Hackney, and Price, 1965). Spectinomycin dihydrochloride pentahydrate (Trobicin) is more soluble than the sulphate so enabling the use of a smaller volume of diluent.

In the present study, $2 \mathrm{~g}$. spectinomycin hydrochloride was used in the treatment of uncomplicated gonorrhoea in males and females.

\section{Patients and methods}

The 348 patients studied, 243 males and 105 females, were all diagnosed and treated at the Out-Patients Department for Venereal Diseases, University Central Hospital, Helsinki from January to April, 1973. Specimens for direct microscopy and culture were taken from the urethra in males and from the urethra, cervix, and rectal mucosa in females before treatment and at each follow-up visit. The male patients were seen once, 7 to 14 days after treatment, and the female patients twice, 7 to 14 and 14 to 21 days after treatment. The specimens for culture were transported in Stuart's medium to the Department of Serology and Bacteriology, University of Helsinki, and cultured on two Thayer-Martin media, one of which also contained trimethoprim. Although treatment was given on the basis

Received for publication, November 14, 1973 of a smear diagnosis, only the cases confirmed by culture (including fermentation reactions) were included in the assessment. Sensitivity tests to penicillin G and spectinomycin were carried out by the plate-dilution method described by Reyn, Korner, and Bentzon (1958).

The spectinomycin hydrochloride was given as a single intramuscular injection of $2 \mathrm{~g}$. in both males and females.

\section{Results}

The results of treatment are summarized in Table I.

Twelve men ( 7 per cent.) still had a positive culture when re-examined, but four of them admitted to possible re-infection. Thus probable true failure occurred in eight ( 5 per cent.) of the men. Six women (7 per cent.) had a positive culture at their first follow-up visit and none of these admitted to further exposure to risk of infection.

TABLE I Results of treament with spectinomycin

\begin{tabular}{|c|c|c|c|c|c|}
\hline \multirow[t]{3}{*}{ Sex } & \multicolumn{3}{|c|}{ No. of patients } & \multirow{2}{*}{\multicolumn{2}{|c|}{$\begin{array}{l}\text { Positive culture after } \\
\text { treatment }\end{array}$}} \\
\hline & \multirow[t]{2}{*}{ Treated } & \multicolumn{2}{|c|}{ Followed-up } & & \\
\hline & & No. & Per cent. & No. & $\begin{array}{l}\text { Percentage of those } \\
\text { followed }\end{array}$ \\
\hline $\begin{array}{l}\text { Male } \\
\text { Female }\end{array}$ & $\begin{array}{l}243 \\
105\end{array}$ & $\begin{array}{r}172 \\
91\end{array}$ & $\begin{array}{l}71 \\
87\end{array}$ & $\begin{array}{r}12 \\
6\end{array}$ & $\begin{array}{l}7 \\
7\end{array}$ \\
\hline Total & 348 & 263 & 76 & 18 & 7 \\
\hline
\end{tabular}

The results of the sensitivity tests to spectinomycin and penicillin $G$ are presented in Table II (overleaf).

There seemed to be no clear correlation between the resistance of the gonococcal strains to the two antibiotics.

The Figure (overleaf) relates the treatment results to the sensitivity of the strains to penicillin and spectinomycin in 257 of the 263 patients who attended for follow-up and in whose cases the sensitivity tests had been carried out to both antibiotics. All the true 
TABLE II Sensitivity of 332 gonococcal strains to spectinomycin and penicillin (six strains were lost in subculture)

\begin{tabular}{|c|c|c|c|c|c|}
\hline \multirow{2}{*}{$\begin{array}{l}\text { Minimum inhibitory } \\
\text { concentration of } \\
\text { spectinomycin }(\mu \mathrm{g} . / \mathrm{ml} .)\end{array}$} & \multicolumn{5}{|c|}{$\begin{array}{l}\text { Minimum inhibitory concentrations of } \\
\text { penicillin } G(i . u . / \mathrm{ml} .)\end{array}$} \\
\hline & $0.01-0.1$ & $0 \cdot 2$ & 0.5 & $1 \cdot 0$ & Total \\
\hline $2 \cdot 5$ & 3 & & 1 & & 4 \\
\hline $5 \cdot 0$ & 15 & & 1 & & 16 \\
\hline $7 \cdot 5$ & 57 & 11 & 16 & 2 & 86 \\
\hline 10.0 & 98 & 15 & 32 & 6 & 151 \\
\hline 15.0 & 57 & 3 & 6 & & 66 \\
\hline 20.0 & 5 & 2 & & & 7 \\
\hline 40.0 & 2 & & & & 2 \\
\hline
\end{tabular}

treatment failures occurred among the patients with strains with MICs of spectinomycin of 7.5 to $15.0 \mu \mathrm{g} . / \mathrm{ml}$. Six (3 per cent.) of the true failures occurred among the 189 strains with MICs of penicillin $\leqq 0 \cdot 1 \mathrm{i} . \mathrm{u} . / \mathrm{ml}$. and eight (12 per cent.) among 68 strains with MICs $\leqq 0.2 \mathrm{i} \cdot \mathrm{u} / \mathrm{ml}$. This difference was highly significant $(P<0.001)$.

\section{Discussion}

The average cure rate with 2 to $4 \mathrm{~g}$. spectinomycin in uncomplicated gonorrhoea has been given as about 94 per cent. (range 90 to 100 ) in several clinical reports (Cornelius and Domescik, 1970; Platts, 1970; Duncan, Holder, Roberts, and Knox, 1972; Gallai, Sylvestre, and Brault, 1972; Pedersen, Wiesner, Holmes, Johnson, and Turck, 1972; Hafermann and others, 1973; Reyn, Schmidt, Trier, and Bentzon, 1973; Stratigos, Marsellou-Kinti, Kassimatis, and Daikos, 1973). Hafermann and others (1973) reported a cure rate of 95 per cent. in Asian-acquired gonorrhoea, which is known to be highly resistant to penicillin. As spectinomycin can also be used for patients allergic to penicillin, it seems to be an excellent alternative to penicillin in these circumstances.

The present study showed a cure rate of the same order as in earlier reports. The same dosage was used in both males and females and the results did not

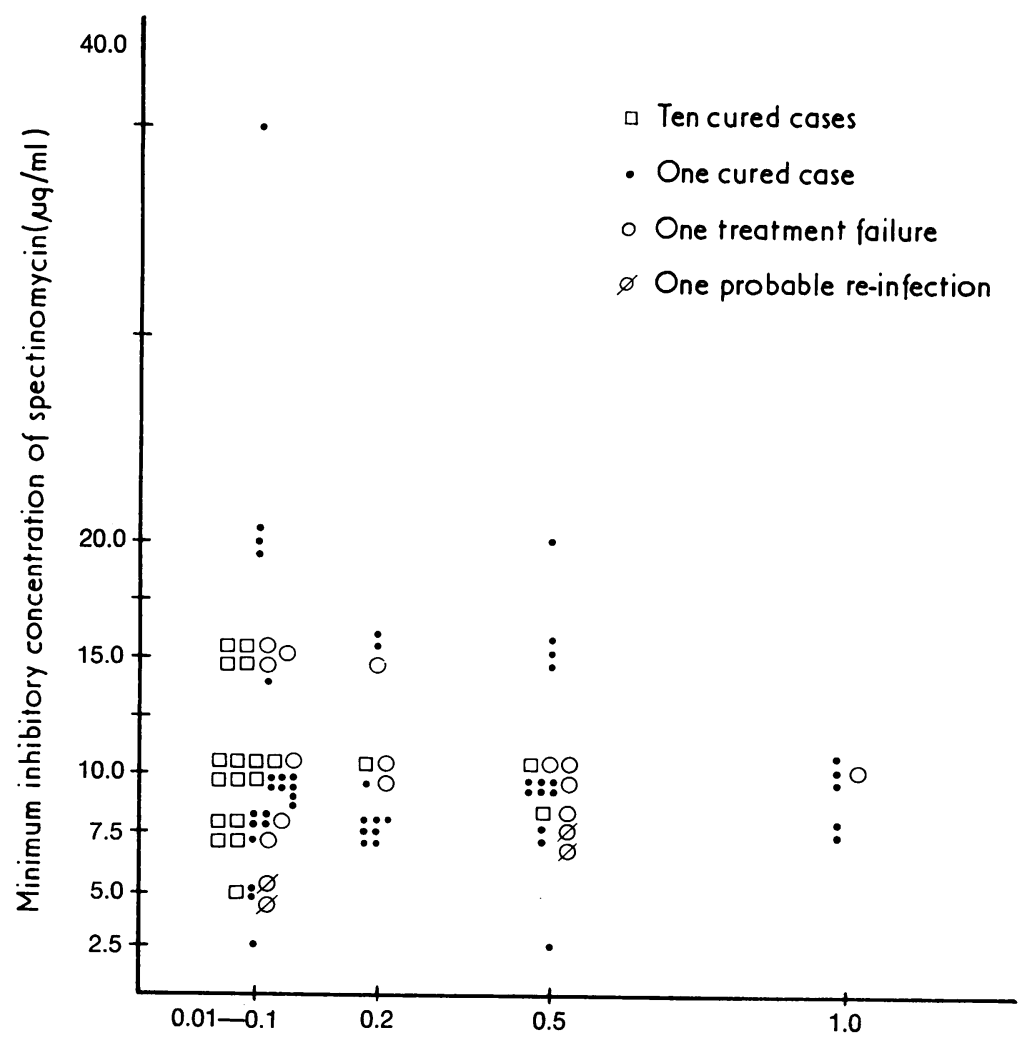

FIGURE Recurrence of gonorrhoea related to spectinomycin and penicillin sensitivities in 257 cases (six strains were lost in subculture) 
differ significantly between the two sexes. The cured patients reported relief of symptoms within 1 to 2 days after the treatment, which correlates well with the report of Sinanian, Panzer, and Atkinson (1972) that gonococci are rapidly eradicated after spectinomycin treatment.

Although there seems to be no definite correlation between the results of the sensitivity tests to spectinomycin and penicillin in this series, there were significantly more treatment failures among the cases with organisms showing decreased sensitivity to penicillin. This differs from the findings of Hafermann and others (1973). However, we feel that $2 \mathrm{~g}$. spectinomycin may not be sufficient for strains less sensitive to penicillin and that in such cases a dose of $4 \mathrm{~g}$. spectinomycin should be used. On the basis of our findings, such strains seem to have definitely increased in Finalnd since 1971 (Lassus, Renkonen, Johansson, and Förström, 1973). On the other hand, when spectinomycin is used because of penicillin allergy, a dose of $2 \mathrm{~g}$. is sufficient in both sexes.

\section{Summary}

A single injection of $2 \mathrm{~g}$. spectinomycin hydrochloride pentahydrate was given to each of 243 males and 105 females with uncomplicated gonorrhoea. The cure rate was 93 per cent. among the 263 patients who returned for follow-up. There was no correlation between spectinomycin and penicillin sensitivities, but there were more treatment failures among the cases harbouring gonococci with decreased sensitivity to penicillin. No side-effects were observed.

\section{References}

Amies, C. R. (1967) Canad. med. Ass. F., 96, 33

CoRnelius, C. R., and Domescik, C. (1970) Brit. F. vener. Dis., 46, 212

Duncan, W. C., Holder, W. R., Roberts, D. P., and Knox, J. M. (1972) Antimicrob. Agents Chemother., 1, 210

Feinberg, S. M. (1961) f. Amer. med. Ass., 178, 815
Gallai, Z., Sylvestre, L., and Brault, J.-P. (1972) Canad. Family Physician, 18, 69

HafermanN, D. R., Cooper, T. S., and ChesNey, M. A. (1973) Milit. Med., 138, 14

LAIRD, S. M., and TAYLOR, G. (1962) Brit. F. vener. Dis., 38,60

Lassus, A., Renkonen, O-V., Johansson, E. A., and FörströM, L. (1973) Acta derm.-venereol. (Stockh.), 53, 233

Pedersen, A. H. B., Wiesner, P. J., Holmes, K. K., Johnson, C. J., and Turck, M. (1972) f. Amer. med. Ass., 220, 205

Platts, W. M. (1970) Med. F. Aust., 12, 500

Reyn, A., Korner, B., and Bentzon, M. W. (1958) Brit. f. vener. Dis., 34, 227

, Schmidt, H., Trier, M., and Bentzon, M. W. (1973) Ibid., 49, 54

Sinanian, R., Panzer, J. D., Atkinson, W. H. (1972) Clin. Med., 79, no. 9, p. 15

Sparling, P. F. (1972) Med. Clin. N. Amer., 56, no. 5, p. 1133

- - Yobs, A. R., Billings, T. E., Hackney, J. E. (1965) In 'Antimicrobial Agents and Chemotherapy', ed. G. L. Hobby, p. 689, American Society for Microbiology

Stratigos, J. D., Marsellou-Kinti, O., Kassimatis, V., and DaIKos, G. K. (1973) Brit. F. vener. Dis., 49, 60

Tiedemann, J. H., Hackney, J. F., and Price, E. V. (1965) F. Amer. med. Ass., 191, 89

WILlCox, R. R. (1959) Practitioner, 182, 328

- (1962) Brit. F. vener. Dis., 38, 150

Le chlorhydrate de spectinomycine dans le traitement de la gonococcie non compliquée chez l'homme et chez la femme

\section{SOMMAIRE}

243 hommes et 150 femmes atteints de gonococcie non compliquée furent traités par une injection unique de $2 \mathrm{~g}$ de chlorhydrate de spectinomycine pentahydratée. Le taux de guérison fut de 93 pour cent pour les malades qui revinrent au contrôle. Il n'y eut pas de corrélation entre les sensibilités à la spectinomycine et à la pénicilline, mais il y eut plus d'échecs thérapeutiques chez les malades hébergeant des gonocoques de sensibilité diminuée à la pénicilline. Aucun effet secondaire ne fut observé. 